\title{
New Geographies of Accumulation, Globalising Firm Networks and the Role of the Auckland Region in the Australasian Economy
}

\author{
Susan Fairgray, Christine Tamásy and Richard Le Heron
}

Susan Fairgray, School of Environment, The University of Auckland, New Zealand

Christine Tamásy, Niedersachsen Competence Centre for the Food Industry (NieKE), Food Initiative Niedersachsen, University of Vechta (ctamasy@ispa.uni-vechta.de)

Richard Le Heron, School of Environment, The University of Auckland, New Zealand (r.leheron@auckland.ac.nz)

\begin{abstract}
Surprisingly little theoretical or empirical research is available on Auckland's actual functional and geographic connectivity, including developments relating to closer economic relations with Australia. This paper draws on the geography of accumulation literatures to argue that close attention must be given to developments in the three circuits of capital (trade, production and finance) if the changing character and contributions of globalising firm networks are to be discerned and understood. The empirical investigations show that for Australian owned firms globalising rather than purely Australasian networks are the norm, network complexity is considerable and that it makes sense to think of Auckland's economy in globalising terms. A globalising networks perspective means that estimates of the magnitude and assessments of the character of employment contributions of Australian owned firms to the Auckland economy reflects these interdependencies.
\end{abstract}

Keywords: new geographies of accumulation, globalising firm networks, regional development, Australasia, New Zealand, Auckland

\section{Introduction}

Restructuring in many countries since the 1980s has involved a re-regulation of state and other governing models in favour of neo-liberal regulatory economic environments. This has placed a premium on taking 'the rest of the world seriously' (Thrift, 1985) by developing geographical knowledge that reveals the situated, contextual and embedded nature of regions. Conceptual and theoretical work by Australian and New Zealand economic geographers has explored how in an increasingly globalising world economy new geographies of accumulation accompany restructurings in the spheres of trade, production and finance and in organisations, industries and territories (e.g., Britton and Le Heron, 1991; Fagan, 1990; Fagan and Le Heron, 1994; Le Heron, 1991, 1993; Pritchard and Fagan, 1999). Internationally recent conceptualisations emphasise the rise of globalising networks ${ }^{1}$ (GNs), especially those

\footnotetext{
${ }^{1}$ The term globalising networks (GNs) is used in the paper as a shorthand for the three circuits of capital: commodity capital circuit (globalising through trade), money capital circuit (globalising through the rise of investment capital) and productive capital (globalising through production linkages and value chains). The convention is adopted for three reasons. First, the idea of networks potentially linking any part, rather than necessarily all parts, of the world is consistent with the geographies of accumulation framework. Second, while most research has focused on global production networks, this emphasis ignores two circuits of capital, globalising through trade and finance. Third, the term network is less abstract than that of a circuit and more readily intersects with the every day world of firms.
} 
associated with various dimensions of global commodity chains, global value chains and global production networks (e.g., Coe et al., 2004, 2007, 2008; Dicken, 2007; Dicken et.al., 2001; Fold and Pritchard, 2005; Hughes and Reimer, 2004), the connectivity of clusters into processes operating at a range of geographic scales (e.g., Eradyn, 2002), and geographically informed theories of the firm (Dicken and Malmberg, 2001; Taylor and Asheim, 2001). Very much as a result of converging research trajectories local areas are increasingly seen as consisting of multi-scalar, relational and interconnected entities (e.g., firms, government agencies, community organisations) in geographically varied network formations, many of which tie into and/or shape global production networks (Hess and Yeung, 2006) ${ }^{2}$. Most studies on the emergence and development of the new economic configurations have looked at specific industries and organisations. Region-centred research is for the most part absent (one of the few exceptions is, for example, Yeung, 2009). This is somewhat surprising given the surge of interest in the positioning of regions, rather than nations, in the globalising economy (MacLeod, 2001; Florida, 1995; Wolfe and Gertler, 2001).

However, conceptualising globalising processes in terms of dynamic circuits of capital implies a new generation of research questions and methodologies. Indeed, Yeung (2003) contends that economic geographers should 'explore the microfoundations of economic action ... to generate in a reflexive manner theoretical insights from multi-scalar dimensions of economic action'(emphasis added), because this 'may well be a first methodological step in producing rigorous new economic geographies that enables geographers to be placed firmly back in diverse policy circles'. We would like to take up the challenge, with reference to an investigation of transformations relating to an open neo-liberalising economy and institutional environment, the Auckland region ${ }^{3}$, New Zealand. We argue that Auckland's role in the Australian economy can only be better understood through firms' integration within wider production networks.

\section{New geographies of accumulation in the Australasian context}

Australasian Geographers have used the geographies of accumulation framework to identify abstract distinctive eras, reflecting the relative but changing importance of different capital circuits and changing regulatory regimes (Britton and Le Heron, 1991; Le Heron and Pawson, 1996). While internationally the post-1945 long boom was characterised by significant developments in the circuit of production capital (Fagan and Le Heron, 1994), New Zealand featured particular structural constraints, by virtue of a strong interventionist state, which constricted accumulation to national development. Options for economic actors during this era were thus limited, with respect to how the spheres of trade, production and finance developed. In the notation of the geographies of accumulation framework, New Zealand firms mainly belonged to the national, investment-constrained or market-constrained fractions of capital, but not the international fraction where interactions would have been international in all three circuits of capital (Le Heron and Pawson, 1996). The investment-constrained fraction was made up of large New Zealand companies that grew by way of mergers and diversification of activities but had found their internationalisation strategies hampered

\footnotetext{
${ }^{2}$ While different literatures are associated with the concepts of global commodity chain, global supply chains and global value chains the idea of networks is recognised as an important common thread in each. While we use these literatures as an entry point for discussion, the region-centred new geographies of accumulation framework is used to conceptualise our empirical study on Auckland's role in the Australasian economy.

${ }^{3}$ The paper adopts the conventional definition of the Auckland region, namely the seven territorial local authorities (TAs), Rodney District, North Shore City, Waitakere City, Auckland City, Manukau City, Papakura District and Franklin District.
} 
by constraints on their investment behaviour. The firms could not easily engage with the rest of the world because of a range of barriers that restricted the level and nature of connectivity offshore. The market-constrained fraction consisted of foreign firms from an early era that were mostly visible in the protected import-substitution industries (Le Heron, 1988).

It made little sense in this structural context to consider Auckland's population and economic growth in terms other than the New Zealand space-economy. In the national press and policy circles Auckland's population was regarded as growing too fast, the city was considered too big because of its primate city status and the city was too reliant on import-substitution activities. Geographers investigating the New Zealand space-economy adopted a region, industry and enterprise perspective (Taylor and Le Heron, 1977), which necessarily forced to the fore questions about Auckland's economic character and the nature and contributions of Auckland's enterprises and industries (Franklin, 1978). Although reflecting the orthodoxy of linkage studies at the time two conclusions are still apposite. Auckland was attracting a disproportionate share of higher order company head offices (Cant and Johnston, 1973; Hayward, 1996), the result of Auckland firms expanding their branch strategies into other New Zealand, often through amalgamations and mergers. Auckland manufacturers in particular supplied a growing domestic market rather than developing export oriented activities (Le Heron, 1980a, 1980b).

New Zealand's state-led restructuring throughout the 1980s reconfigured the economy (Britton and Le Heron, 1991), leading to the disappearance of the investment and market constrained fractions. The arena for accumulation was both enlarged (in geographic extent) and reshaped (by the new economic actors). New Zealand's economic landscape came to comprise national and international fractions of capital. This led gradually to much change; for example, the re-constitution of New Zealand's agri-food supply chains (Le Heron et al., 2001), episodes of turbulence following global pressures (1987 share market crash), new levels of success and failure of expansionary 'New Zealand' companies (the forestry multinationals, the white ware company Fisher and Paykel, the global dairy giant Fonterra), interest in New Zealand assets released through privatisation processes. Importantly restructuring aided the steady emergence of Closer Economic Relations (CER) with Australia with some noticeable effects. ${ }^{4}$ First, it initially facilitated and altered the nature of trade (Holmes, 1990) between Australia and New Zealand. This was rapidly superseded by wider developments in finance and production, once the neo-liberalisation agenda became entrenched as New Zealand's model of economic management. Second, for a relatively brief period, the goal of economic integration attracted research attention. This research has been concerned with increased linkages and similarities between both economies (Catley, 2001).

However, not withstanding the research emphasis on integration, the spatial economic structures of Australasian integration have been ignored. Most research on the Australasian economy has been concerned with increased linkages and similarities between the national economies of New Zealand and Australia (Catley, 2001). This includes investigations of trade (Briggs and Ballingall, 2001; Vautier, 1990; Edwards and Holmes, 1994), investment (Downie, 1990) and population flows (Bushnell and Choy, 2001) as well as the alignment of policy development (Farmer, 1990) and cooperation within larger international political and defence agendas (Holmes, 2002). Story (2004) provides an alternative perspective on an integrated Australasian market using the lens of firm expansion strategies. This has occurred within Australasia,

\footnotetext{
${ }^{4}$ Closer Economic Relations (CER) is a free trade agreement between the governments of New Zealand and Australia (signed in 1983).
} 
although successful expansion has more easily been achieved in Australian companies entering the New Zealand market (Bennett, 2006). Holmes (2002) shows that recent favourable conditions within the New Zealand domestic economy have made it an attractive area for Australian firms to expand their domestic operations. Indeed, the spatiality of investment linkages and cross-border firm structures is beginning to be recognised. What the theoretical literatures and empirical evidence clearly suggest is that Auckland and its economic actors must be understood as situated within not only the national economy, but the Australasian and other international economies.

\section{Data collection process}

A database of all identified Australian owned establishments in Auckland was constructed for this study (Fairgray, 2006) to apply a firm-level approach to globalising networks. Cross-border firms through parent and subsidiary firm ownership structures are defined as an enterprise having a 51 percent or larger ownership share of another enterprise, where the former is the parent and the latter the subsidiary. In effect a majority shareholding constitutes a strong controlling interest in a firm. Furthermore, all firms operating in Auckland that have direct ownership linkages to Australia upon exiting New Zealand borders are included. This methodological framework included both firms with an ultimate parent in Australia and with no intermediate parents between Auckland subsidiaries and Australian parents, and those linked via intermediary parents to larger international structures with ultimate parents elsewhere in the world. Functional linkages in Australian cross border ownership structures highlight the integration of Auckland within wider scales of production. Auckland is structured within Australasia through functional firm linkages to Australian parent firms and consequently, wider networks in the global economy.

Available secondary data sets were only starting points for the empirical investigation, though none of the individual data sets in New Zealand could be used to systematically examine activity types, enterprise sizes and cross-border functional linkages of firms operating in Auckland by foreign ownership structures. The construction of the new database involved several steps. A commercial directory by AP Information Services Ltd and Dun \& Bradstreet (2005) provided the foundation database framework, identifying trans-Tasman parent-subsidiary firm structures. Ownership records of subsidiaries within Auckland were verified through readily accessed official information from the New Zealand Companies Office (2006). This step revealed greater complexity of ownership structures and variable levels of information accuracy, necessitating further investigation of potential Australian owned enterprises. Consequently, known dominant enterprises in industry sectors, lists of Auckland's largest (by employment) companies from additional commercial databases (Kompass New Zealand, 2005; New Zealand Business Who's Who, 2005), companies identified through market information internet searches and all enterprises in known Australian dominated sectors (finance and insurance, food manufacturing) were systematically investigated and cross-checked against official records identifying immediate Australian ownership.

The enlarged database was then investigated to determine the Auckland locations of firm distinct activity types at the geographic unit level. The procedures embraced centralised commercially produced sources, selected trade category centralised listings, individual company websites and other individual internet based listings of company addresses ${ }^{5}$. Firm addresses were subsequently geo-coded to

\footnotetext{
${ }^{5}$ Included in these are: Wises Maps online directory (http://www.wises.co.nz); UBD Infored Business Directory (UBD) online (http://www.ubd.co.nz) and Northland and Auckland edition printed directories (UBD, 2004); a'Courts
} 
meshblocks ${ }^{6}$, which were used to spatially match firms to official employment by industry sector data attached to these land parcels (Statistics New Zealand, 2003, 2005). This identified the type and employment size of activity at each location within each firm, allowing comparisons to the total Auckland employment in each industry sector and existing datasets of Auckland employment in enterprises with foreign equity. Further cross-checking procedures were used to verify firm-specific employment figures for Australian owned subsidiaries operating in the Auckland region.

The firm-level database identifies 526 firm groups made up of 2,461 immediate Australian owned units which operate in the Auckland region in 2005. The database is thus an information structure that contains attribute details that transcend New Zealand's borders and so can be examined for network relationships and patterning. In the first instance analysis focuses on the spatial dimensions of existing (potentially global) firm networks, to establish the spatiality of Australian owned firms in Auckland. Firms were further investigated individually to identify their engagement within export and import activity and qualitative aspects of their positioning within cross-border networks and those of the national/regional economy. Extensive internet searches, predominantly through company websites, provided this information. Ultimate ownership beyond Australia was identified, where possible, through available company corporate information and commercial databases containing subsidiary lists of corporations (Mergent, 2005). Collectively this quantified the aggregate employment contribution by industry sector of Australian owned firms in the Auckland regional economy. These approaches gave unique and detailed insight into the economic configuration of Australian firms in the Auckland region. Evidence gathered from a recently completed research project supports our arguments. ${ }^{7}$

\section{Empirical results}

Cross-border dimensions of Australian firm networks: an Auckland perspective

The theoretical discussion highlights grounds as to why the networks of the Australian enterprises need to be thoroughly examined. Table 1 illustrates the broader geographic scale of networks into which Auckland enterprises with immediate Australian ownership with over 100 total employees are embedded. It is organized by the ultimate country of incorporation (Australia, USA, other and total) where this ownership supersedes immediate Australian ownership, the 'apparent' face of ownership. ${ }^{8}$ This provides an indication of how the Australian owned firms found in Auckland have in their backgrounds multiple networks involving the different spheres of finance, trade and production with geographically and functionally interconnecting networks. Enterprises typically occupy multiple positions within different networks,

\footnotetext{
Business Handbook online directory (http://www.acourts.co.nz); Industry Search (http://www.industrysearch.com.au), an online Australian manufacturing and industrial trades listings site; the New Zealand Companies Office (NZCO), a business unit of the central government Ministry of Economic Development; Telecom New Zealand White Pages (http://www.whitepages.co.nz) and Yellow Pages online (http://www.yellowpages.co.nz) directories; NBO National Business Online (http://www.nbo.co.nz), a New Zealand based online business listing directory; TPL Online (http://www.tplonline.co.nz), an online listing of specific industry online directories; MarketNewZealand.com, a New Zealand Trade \& Enterprise (NZT\&E) New Zealand exporter directory (http://www.marketnewzealand.com/mnz/browse.aspx); the Ministry of Agriculture and Forestry online 2005 listings of companies addresses which are able to receive sea containers (MAF, 2005); Google and Telecom Xtra New Zealand search engines; and individual company websites.

${ }^{6}$ This refers to the smallest land parcel boundaries which are used by Statistics New Zealand.

${ }^{7}$ Personal interviews with five top executives of leading Australian owned companies were conducted by Christine Tamásy in May/June 2009. The project was funded by the German Research Foundation (grant no. Ta 277/2-2).

${ }^{8}$ Each cell displays the number of enterprises which have some form of organisation operating at that scale. The entries in each cell include the scale of integrated operations within an ownership structure, intra-firm and inter-firm sourcing and distribution networks, financial circuits and inter-firm affiliated networks.
} 
which from the point of view of the firms, are organized on different spatial scales; Australasian (Australia and New Zealand), Asia-Pacific, international and global ${ }^{9}$ scales, the latter ones encapsulating networks spanning a wider geographic area than the Asia-Pacific region. Thus, to illustrate, an enterprise may be simultaneously structured within integrated intra-firm Australasian production operations, inter-firm Asia-Pacific supplier networks and intra-firm global financial ownership structures. Crucially, it can be seen that 76 enterprises with Australian ultimate ownership are also integrated into wider inter-firm global networks.

Table 1: Geographical scale of operations of Australian enterprises in Auckland* by country of ultimate incorporation, 2005

\begin{tabular}{lrrrrrr}
\hline \multicolumn{7}{c}{ Geographical Scale of Operations } \\
\hline $\begin{array}{l}\text { Ultimate country } \\
\text { of incorporation }\end{array}$ & Australasian & $\begin{array}{c}\text { Asia- } \\
\text { Pacific }\end{array}$ & International & Global & NIA & $\begin{array}{r}\text { Number of } \\
\text { enterprises }\end{array}$ \\
\hline Australia & 67 & 24 & 17 & 45 & 1 & 82 \\
USA & 10 & 4 & 2 & 15 & 0 & 17 \\
Other & 4 & 4 & 0 & 16 & 8 & 24 \\
\hline Total & $\mathbf{8 1}$ & $\mathbf{3 2}$ & $\mathbf{1 9}$ & $\mathbf{7 6}$ & $\mathbf{9}$ & $\mathbf{1 2 3}$ \\
\hline
\end{tabular}

* with more than 100 employees

NIA $=$ no information available

Source: Fairgray (2006)

Given the high incidence of identifiably Australasian scale operations, Rosenberg's (1997) concerns about Australasian level rationalisation are pertinent. This has typically occurred through foreign takeover and subsequent closure of New Zealand operations. This issue can be probed by determining Auckland's positioning within the value chains at these scales of operation at the firm level. From the regional database dimensions $^{10}$ of the value chain within Auckland can be ascertained. Central to this is highlighting the type of functional linkages between Auckland subsidiaries and Australian parent firms and other parts of the wider GN.

The empirical evidence shows very different contributions to the networks of the ultimately Australian versus ultimately USA and Other (e.g., UK, Germany, Japan and France) firms with respect to geographical scale of operations. Out of the total 123 'Australian' enterprises, 81 have ultimate Australian ownership, with the ultimate USA and Other 'Australian' companies accounting for a further 42 enterprises (Table 1). Two very different points emerge from the detailed checking of individual enterprise unit cross-border networking in the database. First, of those with ultimate Australian ownership, 67 are set in Australasian scale networks, 24 are incorporated within AsiaPacific scale networks and several are in international and global scale networks. This enlarged scope of the networks has Auckland and Australasian origins. The defining feature of the majority of the Australian owned enterprises is that they have integrated production operations on an Australasian scale and their overall operations involve mainly Australasian level intra-firm networks. Moreover, while production arrangements are mostly intra-firm, financial, $\mathrm{R} \& \mathrm{D}$, sourcing and distribution networks are both intra- and inter-firm and extend beyond Australasia to the Asia-Pacific. This is

\footnotetext{
${ }^{9}$ Globalising networks are included as two categories, international and global. The categories refer to networks ranging from spanning a few countries outside the Asia-Pacific area (international networks) to those connecting multiple regions of the globe (global networks).

${ }^{10}$ The database's reliance on secondary sources means the assessment can only scope dimensions and be a first approximation of networking configurations.
} 
further influenced by which components of value chain development can occur in Auckland. Furthermore, the globally operating firms treat Auckland and New Zealand and also Australia as secondary markets within their organizational frameworks. This means Auckland and New Zealand have to be seen as set in pre-existing international and global networks. Whether the main impetus for network development is from within the USA and Other countries or from initiatives from Auckland or elsewhere in Australasia cannot be established from the database records. What can be documented is that spatial proximity to the Australian market is regarded as a necessary condition to gain critical mass for Auckland or New Zealand based operations.

Large variability occurs within and across sectors. Of considerable importance is the presence and level of foreign firm manufacturing in Auckland, compared to solely distribution stages of the GN. This included instances of full manufacturing within Auckland or New Zealand with the export of finished commodities through distribution channels associated with the wider GN, processing spatially immobile factor endowments. An example is Bluescope Steel/New Zealand ${ }^{11}$, a leading steel company, which operates a fully integrated steel mill at Glenbrook, in the south of the Auckland region to process New Zealand's West Coast iron sand resources. The parent firm Bluescope Steel has equivalent operations in Australia where production of steel occurs within a highly vertically integrated structure. However, significant inter-firm linkages occur through the intermediary supplier inputs to other steel related activities within the domestic economy and processing activities further downstream in steel production related commodities. Integrated operations on Australasian and Asia-Pacific scales have achieved sufficient critical mass to establish distribution linkages within the international arena. This has also occurred through the development of strategic alliances with related sector enterprises in foreign markets, particularly the USA. The importance of these linkages to Auckland is paramount where approximately 60 percent of Bluescope's Auckland production is exported. These functional production linkages within the Australasian economy show how Australian owned firms embed the Auckland regional economy into wider international networks. Furthermore, the example illustrates that wider external linkages are not restricted to ownership networks because subsidiaries can be integrated into wider GNs as a result of access to parent firm networks.

To summarise, Auckland is structured at the firm level into wider GNs at Australasian, Asia-Pacific and global scales, where the former is typically a subset of the larger scales. This is widespread, across the range of sectors. The development of Australasian scale activities is well advanced. The ownership direction of wider linkages from an Australasian scale involves two directions: Australasian operations have increasingly expanded outward into the Asia-Pacific and global scales; while firms in the global arena have entered Auckland at the Australasian scale. A tightening focus on core competencies within larger ownership structures has been influential in these developments. Ownership GNs have typically either entered the Auckland or Australasian region through a series of mergers and acquisitions of existing related operations or the establishment of new enterprises that are an extension of wider operations. The latter has taken place via branch plant production operations in the local market or simply setting up distribution channels.

The findings illustrate that Auckland is integrated significantly within Australasia and in turn wider spheres where linkages occur at the firm level. The evidence also suggests that these contribute toward Auckland's role within the New Zealand economy in two areas: firstly, the distribution of physical commodities from

\footnotetext{
${ }^{11}$ Bluescope Steel Ltd/NZ Steel Ltd is the $11^{\text {th }}$ largest employer in the Auckland regional economy (Table 3).
} 
Auckland to the rest of New Zealand; and secondly, the coordination of national operations of these subsidiaries through Auckland. The high levels of integration into wider Australasian, Asia-Pacific and global structures, however, beg the question of the level of impact this feature has regionally within Auckland.

Employment impacts of Australian firms in Auckland

In the following the Australian presence in the Auckland economy is investigated by using employment figures of Australian owned companies. Table 2 shows 68,172 total employees (ECs) in the 2,461 immediate Australian owned units (526 firm groups). Investment is concentrated into certain sectors. Finance \& Insurance and Manufacturing are the largest sectors of investment with 15,261 and 14,285 employees respectively, followed by high levels of investment in Retail Trade. Concentrations of investment occur also at the sub-sector level, though these stem from a few large firms. Within most sectors a few noticeably larger enterprises dominate investment in the sector. Table 2 also shows that nearly 70 percent of total employment in Finance \& Insurance in Auckland is comprised by employment in Australian owned firm.

Table 2: Employees in Australian owned enterprises (AoE) in Auckland, 2005

\begin{tabular}{lrrrrr}
\hline 1-Digit ANZSIC Sector & EC in AoE & $\begin{array}{c}\text { Total } \\
\text { Auckland } \\
\text { EC }\end{array}$ & A/B*100 & $\begin{array}{c}\text { Auckland } \\
\text { total FE* EC }\end{array}$ & A/D*100 \\
\hline & A & \multicolumn{1}{c}{ B } & \multicolumn{1}{c}{ C } & D & E \\
\hline Agriculture, Forestry \& Fishing & 10 & 1650 & 0.61 & 190 & 5.26 \\
Mining & 0 & 200 & 0.00 & CD & 0.00 \\
Manufacturing & 14285 & 90190 & 15.84 & 27400 & 52.14 \\
Electricity, Gas \& Water Supply & 0 & 2000 & 0.00 & CD & 0.00 \\
Construction & 2313 & 28090 & 8.23 & 4190 & 55.20 \\
Wholesale Trade & 8563 & 52120 & 16.43 & 20260 & 42.27 \\
Retail Trade & 11471 & 68140 & 16.83 & 14670 & 78.19 \\
Accommodation, Cafes \& Restaurants & 317 & 26900 & 1.18 & 5500 & 5.77 \\
Transport \& Storage & 4297 & 28290 & 15.19 & 7600 & 56.54 \\
Communication Services & 942 & 11640 & 8.09 & CD & CD \\
Finance \& Insurance & 15261 & 22150 & 68.90 & 15590 & 97.89 \\
Property and Business Services & 7371 & 84280 & 8.75 & 24880 & 29.63 \\
Government Administration \& Defence & 0 & 17640 & 0.00 & 0 & 0.00 \\
Education & 41 & 41540 & 0.10 & 540 & 7.64 \\
Health \& Community Services & 782 & 46420 & 1.68 & 1090 & 71.74 \\
Cultural \& Recreational Services & 1104 & 15700 & 7.03 & 2530 & 43.64 \\
Personal \& Other Services & 1415 & 18380 & 7.70 & 1900 & 74.45 \\
\hline Total & $\mathbf{6 8 1 7 2}$ & $\mathbf{5 5 5 3 3 0}$ & $\mathbf{1 2 . 2 8}$ & $\mathbf{1 2 6 3 4 0}$ & $\mathbf{5 3 . 9 6}$ \\
\hline
\end{tabular}

* A foreign enterprise (FE) is defined as an enterprise with $50 \%$ or more foreign equity (in 2004)

$\mathrm{EC}=$ employee count

$\mathrm{CD}=$ confidential data

Source: Fairgray (2006) and SNZ (2005) Business Activity Statistics

Table 3 identifies and ranks the largest 30 Australian firms by number of employees in Auckland. Progressive Enterprises, the biggest firm group, employs 7,322 persons, mostly in the supermarket retail sector. The next largest employer in the retail sector is the Briscoes Group, operator of large format Rebel Sport and Briscoes Homeware chain stores with 1,724 employees in Auckland. Following that are Coles Myer, trading as department store Kmart, and Whitcoulls operating the books and stationery chain store franchise, employing 678 and 542 persons respectively. These 
investments, with the exception of Whitcoulls, are multiple location larger format stores. Furthermore, each occupy significant market positioning ${ }^{12}$ within their sectors benefiting from scale advantages over a significant proportion of the individual smaller domestically owned stores. However, these stores are oriented toward the domestic market for Auckland and so do not possess significant potential to boost the size of Auckland's economy.

Table 3: Largest 30 Australian enterprises by predominant industry sector in Auckland, 2005*

\begin{tabular}{|c|c|c|c|c|c|}
\hline Rank & 1-Digit ANZSIC Sector & Name & Total Employment & $\begin{array}{c}\text { Cumulative } \\
\text { Australian } \\
\text { Employme } \\
\text { nt } \\
\end{array}$ & $\underset{\%}{\text { Cum. }}$ \\
\hline 1 & Retail Trade & Progressive Enterprises Ltd & 7322 & 7322 & 10.74 \\
\hline 2 & Finance \& Insurance & ASB Bank Ltd & 4108 & 11430 & 16.77 \\
\hline 3 & Finance \& Insurance & BNZ Bank Ltd & 2506 & 13935 & 20.44 \\
\hline 4 & Finance \& Insurance & Westpac Bank Ltd & 2125 & 16060 & 23.56 \\
\hline 5 & Finance \& Insurance & ANZ/National Bank Ltd & 2001 & 18062 & 26.49 \\
\hline 6 & Transport \& Storage & Toll Group (NZ) Ltd & 1877 & 19939 & 29.25 \\
\hline 7 & Retail Trade & Briscoe Group Ltd & 1724 & 21663 & 31.78 \\
\hline 8 & Personal \& Other Services & Spotless Services (NZ) Ltd & 1720 & 23383 & 34.30 \\
\hline 9 & Finance \& Insurance & Telstra Clear Ltd & 1440 & 24823 & 36.41 \\
\hline 10 & Manufacturing & $\begin{array}{l}\text { Wilson \& Horton Ltd } \\
\text { Bluescope Steel Ltd/NZ }\end{array}$ & 1282 & 26104 & 38.29 \\
\hline 11 & Manufacturing & Steel Ltd & 1268 & 27372 & 40.15 \\
\hline 12 & Manufacturing & Allied Foods Ltd & 845 & 28217 & 41.39 \\
\hline 13 & Manufacturing & Goodman Fielder Ltd & 760 & 28977 & 42.51 \\
\hline 14 & Manufacturing & Coca-Cola Amatil Ltd & 749 & 29726 & 43.60 \\
\hline 15 & $\begin{array}{l}\text { Construction } \\
\text { Property \& Business }\end{array}$ & Transfield Services Ltd & 739 & 30464 & 44.69 \\
\hline 16 & Services & PMP Ltd & 727 & 31191 & 45.75 \\
\hline 17 & Manufacturing & Amcor Packaging Ltd & 718 & 31909 & 46.81 \\
\hline 18 & $\begin{array}{l}\text { Finance \& Insurance } \\
\text { Health \& Community }\end{array}$ & Promina Group Ltd & 718 & 32626 & 47.86 \\
\hline 19 & Services & Sonic Healthcare Ltd & 688 & 33314 & 48.87 \\
\hline 20 & Retail Trade & Coles Myer Ltd t/a Kmart & 678 & 33992 & 49.86 \\
\hline 21 & Manufacturing & Visy Ltd & 597 & 34589 & 50.74 \\
\hline 22 & Manufacturing & ION Ltd & 570 & 35159 & 51.57 \\
\hline 23 & Finance \& Insurance & AMP Ltd & 556 & 35715 & 52.39 \\
\hline 24 & Wholesale Trade & Hewlett-Packard Ltd & 550 & 36265 & 53.20 \\
\hline 25 & Retail Trade & Whitcoulls Ltd & 542 & 36807 & 53.99 \\
\hline 26 & Wholesale Trade & Orica Chemnet Ltd & 532 & 37338 & 54.77 \\
\hline 27 & Wholesale Trade & Tyco Flow Ltd & 526 & 37864 & 55.54 \\
\hline 28 & Manufacturing & Lion Nathan Ltd & 519 & 38383 & 56.30 \\
\hline 29 & Manufacturing & ACP Media Ltd & 510 & 38893 & 57.05 \\
\hline 30 & Finance \& Insurance & IAG Insurance Ltd & 491 & 39384 & 57.77 \\
\hline
\end{tabular}

*Employment as employee count (EC)

Source: Fairgray (2006)

The five largest banks ASB, BNZ, Westpac and ANZ and National Bank constitute the next largest Australian firm groups in Auckland, with a combined 10,740

\footnotetext{
12 This is not necessarily accurate for Kmart given direct competition from The Warehouse Ltd and indirect competition in overlapping product categories through recent growth in the number of other large format chain stores. However, evidence in a recent article by The New Zealand Herald (2005) documents increased sales and planned expansion.
} 
employees. Also within this sector Telstra Clear comprises the next largest share of employment at 1,440 employees. However, nearly half of these are engaged in telecommunications activity lessening the dominance of this firm in this sector. Insurance companies Promina Group, AMP and IAG collectively employ 1,765 persons. These are umbrella firms to a sizeable number of insurance companies linked into highly complex ownership trees as subsidiaries and related firms. Promina group includes Vero, Asteron, Automobile Association (AA) Insurance and ING insurance firms, while IAG includes IAG, New Zealand Insurance (NZI) and State insurance. Insurance firms, banks and holding companies are integrated through non-controlling interest investments in managed funds and financial company investments ${ }^{13}$. High foreign investment in this sector has effectively integrated Auckland into wider international and global circuits of capital through direct financial linkages between parent and subsidiary firms as well as access to global capital markets through lending access and fund management operations. Also in the tertiary sector printing \& advertising firm PMP Ltd, ranked $16^{\text {th }}$, employs 727 persons in the property \& business services sector.

Large Australian enterprises include large media manufacturing companies, Wilson \& Horton, with the APN Holdings firms as subsidiaries and ACP Media (Australian Consolidated Press). These firms have a dominant market share of the New Zealand local and regional newspaper printing and publishing sector as well as other activities in magazine \& journal publishing, some of which is exported. Other large manufacturing operations typically involve activity based on spatially immobile factor endowments in Auckland and New Zealand. These include the manufacturing of primary commodities in food and other sectors conducted in Bluescope Steel/New Zealand Steel (ranked 11th with 1,268 employees), Allied Foods (12th, 845), Goodman Fielder (13th, 760) and Lion Nathan (28th, 519). Competitors, both in New Zealand and Australasia, Visy and Amcor Packaging are also large Australian firms in Auckland. Large ION automobile manufacturing firm ranked 22nd and employing 570 persons is, however, anticipated to cease operations in New Zealand (Amoore, 2005). Coca-Cola Amatil is ranked 14th employing 749 persons in the manufacturing sector. Similar to other large Australian manufacturers levels of vertical integration are present within Auckland where bottling plants, distribution channels and soft drink manufacturing occur within the same ownership structure (The Coca-Cola Company, 2006).

Other sectors with a presence in the top 30 firms include the wholesale sector, transport \& storage, personal \& other services, construction and health \& community services. This stems from the presence of single large Australian firms: Toll Group, with operations in the domestic road freight and storage sector; Spotless Services, dominant in the cleaning, catering and laundry and uniform hire activities; Transfield Services, involved in buildings and facilities maintenance including electrical services; and Sonic Healthcare operating multiple branch pathology laboratory Diagnostic Medlabs and Mercy Radiology centres in Auckland. Wholesale sector large firms include Hewlett Packard, Tyco Flow and Orica Chemnet. While the latter two also have manufacturing operations locally within the Auckland region they are categorised into the wholesale sector given the dominance of distribution operations of manufactured production. Hewlett-Packard mostly distributes finished manufactured goods to the New Zealand market, representing only the final stages of the production chain within Auckland.

\footnotetext{
${ }^{13}$ A large share of these is not included in the database, as single controlling shareholding interests are often not present
} 


\section{Conclusions}

The paper has argued on theoretical grounds that investigations of the new geographical configurations of the globalising world economy should be attentive to dynamic circuits of capital, even though this is challenging. The empirical analysis of Australian owned enterprises in the Auckland region of New Zealand to explore network dimensions of Australian firms has resulted in a re-assessment of conceptions about the nature of 'Australian' firms and the nature of their economic contributions. Several conclusions can be immediately drawn from the study. First, there is support for the general expectation in the international economic geography literature that in neoliberalising geo-economic and geo-political conditions network structures should feature globalising dimensions. The evidence indicates that multi-scalar networks are the norm, that network complexity is considerable and that it makes sense to think of Auckland's economy in globalising terms. The examination of Australian foreign direct investments (FDI) could be considered a tough test of the development of globalising networks as economic relations between Australia and New Zealand have re-oriented much business activity around this two-country axis. Nonetheless, much evidence of globalising networks was found. Second, without the customised regional database for Auckland neither the geographical scale of networks nor the fuller extent of impacts on Auckland's economy of Australian owned firms could have been investigated. From a regional policy point of view efforts by regional development agencies to develop customised data bases could be invaluable in understanding regional processes and patterns of change. While perhaps expensive to set up and maintain such data sources allow queries about regional enterprises to be made on a more frequent and comprehensive basis and enable discussion to shift from assertion about regional activities to discussion grounded in evidence. Third, the aggregate contribution of Australian enterprises is substantial for the Auckland economy. Direct employment contributions amount to 68,172 total persons, over 12 percent of Auckland's total employment. These are predominantly concentrated into a few key sectors, comprising substantial shares of Auckland's employment in some areas of the economy. Knowledge of both this structural feature and its employment implications has been negligible in the New Zealand literature. Thus, the paper allows deeper understandings of the geographies of accumulation by analysing Auckland's position in the Australasian economy. From a policy viewpoint, the theoretically-informed analyses and findings suggest that economic development initiatives for the Auckland region need to focus on developing network relationships. Auckland's role in the Australian economy can only be usefully conceptualised through functionally integrated firm networks, which possess interdependent multi-scalar roles within the New Zealand, Australasian and global economies and have substantial manifestations within the local economy through a strong Australian presence in Auckland.

\section{References}

Amoore, K. (2005) '500 jobs to go as South Auckland factory closes', The Spark, 24/08/05, http://home.clear.net.nz/pages/wpnz/aug24-05onthejob.htm, as at February 2006.

AP Information Services Ltd and Dunn \& Bradstreet (2005) 'Who Owns Whom 2004/05', London: AP Information Services Ltd.

Bennett, A. (2006) 'Currency union consummation a long time coming', The New Zealand Herald, 03/01/2006. 
Briggs, P. and Ballingall, J. (2001) A comparison of Australia's and New Zealand's export performance using shift share analysis, Report to Treasury, July 2001, Wellington: New Zealand Institute of Economic Research.

Britton, S. and Le Heron, R. (1991) 'Capital, labour and state relations in the analysis of enterprises and restructuring: an Australasian debate', Australian Geographical Studies, 29, 285-312.

Bushnell, P. and Choy, W.K. (2001) “Go West, Young Man, Go West!'? Treasury Working Paper 01/07, Wellington: The Treasury.

Cant, R.G. and Johnston, R.J. (1973) 'Regional development patterns', in R. Johnston (ed.) Urbanisation in New Zealand, Wellington: Reed Education, 15-40.

Catley, B. (2001) Waltzing with Matilda. Should New Zealand join Australia?, Wellington: Dark Horse.

Coe, N.M.; Hess, M.; Yeung, H.W.; Dicken, P. and Henderson, J. (2004) ' Globalizing' regional development: a global production networks perspective', Transactions of the Institute of British Geographers, 29, 468-484.

Coe, N.; Kelly, P.F. and Yeung, H.W.C. (2007) Economic Geography: A Contemporary Introduction, Oxford: Blackwell.

Coe, N.M.; Dicken, P. and Hess, M. (2008) 'Introduction: global production networks debates and challenges', Journal of Economic Geography, 8, 267-269.

Dicken, P. (2007) Global shift: mapping the changing contours of the world economy, $5^{\text {th }} e d$. . London: Sage.

Dicken, P. and Malmberg, A. (2001) 'Firms in territories: A relational perspective', Economic Geography, 77, 345-363.

Dicken, P.; Kelly, P.; Olds, K. and Yeung, H. (2001) 'Chains and networks, territories and scales: towards an analytical framework for the global economy', Global Networks, 1, 89-112.

Downie, B. (1990) 'CER and direct investment - business perspective', in K.M. Vautier; J. Farmer and R. Baxt (eds) CER and Business Competition - Australia and New Zealand in a Global Economy, Auckland: Commerce Clearing House, 215-234.

Edwards, S. and Holmes, F. (1994) CER: Economic Trends and Linkages, Wellington: The National Bank of New Zealand and Institute of Policy Studies.

Eryadin, A. (2002) 'The local embeddedness of firms in Turkish industrial districts: The changing roles of networks in local development', in M. Taylor and S. Leonard (eds) Embedded Enterprise and Social Capital, Aldershot: Ashgate, 269-288.

Fagan, R. (1990) Elders IXL Ltd: Finance capital and the geography of corporate restructuring, Environment and Planning A, 22, 647-666.

Fagan, R. and Le Heron, R. (1994) 'Reinterpreting the geography of accumulation: the global shift and local restructuring', Environment and Planning D, Society and Space, 16, 265-285.

Fairgray, S. (2006) Auckland's Role in the Australasian Economy: Implications for the Auckland Regional Economic Development Strategy, Master Thesis. Auckland.

Farmer, J. (1990) 'The harmonisation of Australian and New Zealand business laws', in M. Vautier; J. Farmer and R. Baxt (eds) CER and Business Competition Australia and New Zealand in a Global Economy, Auckland: Commerce Clearing House, 45-72.

Florida, R. (1995) 'Towards the learning region', Futures, 27, 527-536

Fold, N. and Pritchard, B. (eds) (2005) Cross-continental Food Chains, London: Routledge.

Franklin, H. (1978) Trade, Growth and Anxiety, Wellington: Methuen. 
Hayward, D. (1996) 'Geographies of concentration', in R. Le Heron, and E. Pawson (eds) Changing Places. New Zealand in the Nineties, Auckland: Longman Paul, 73-79.

Hess, M. and Yeung, H. W.-C. (2006) 'Whither global production networks in economic geography? Past, present, and future', Environment and Planning A, $38,1193-1204$.

Holmes, F. (1990) 'CER in the Pacific context - A policy perspective', in K.M. Vautier; J. Farmer and R. Baxt (eds) CER and Business Competition - Australia and New Zealand in a Global Economy, Auckland: Commerce Clearing House, 321-335.

Holmes, F. (2002) An ANZAC Union?, IPS Policy Paper, No 14, Wellington: Institute of Policy Studies.

Hughes, A. and Reimer, S. (Eds) (2004) Geographies of Commodity Chains, London: Routledge.

Kompass New Zealand (2005) Kompass New Zealand Business Search Engine \& Company Information Directory. http://www.kompass.co.nz, as at November 2005.

Le Heron, R.B. (1980a) 'The diversified corporation and development strategy - New Zealand's experience', Regional Studies, 14, 201-218.

Le Heron, R.B. (1980b) 'Exports and linkage development in manufacturing firms: The examples of export promotion in New Zealand', Economic Geography, 56, 281299.

Le Heron, R.B. (1988) 'State, economy and crisis in New Zealand in the 1980s: Implications for land-based production of a new mode of regulation' Applied Geography, 8, 273-290.

Le Heron, R.B. (1991) 'New Zealand agriculture and changes in the agriculture-finance relation during the 1980s', Environment and Planning A, 23, 1653-1670.

Le Heron, R.B. (1993) Globalized Agriculture. Political Choice, Oxford: Pergamon.

Le Heron, R. and Pawson, E. (1996) 'Introduction', in R. Le Heron, and E. Pawson (eds) Changing Places. New Zealand in the Nineties, Auckland: Longman Paul, 1-19.

Le Heron, R.B.; Penny, G.; Paine, M.; Sheath, G.; Pedersen, J. and Botha, N. (2001) 'Global supply chains and networking: a critical perspective on learning challenges in the New Zealand dairy and meat commodity chains', Journal of Economic Geography, 1, 439-456.

MacLeod, G. (2001) 'Beyond soft institutionalism: Accumulation, regulation and their geographic fixes', Environment and Planning A, 33, 1145-1167

Mergent (2005) Mergent Online. http://www.mergentonline.com, as at January 2006.

Ministry of Agriculture \& Forestry (MAF) (2005) MAF Facilities able to receive Sea Containers as at 26 July 2005, Wellington: MAF.

New Zealand Business Who's Who (NZBWW) (2005) The New Zealand Business Who's Who Online Edition, http://www.nzbww.co.nz, as at November 2005.

New Zealand Companies Office (NZCO) (2006) Register Search. http://www.companies.govt.nz/pls/web/dbssiten.main, as at January 2006.

Pritchard, B. and Fagan, R. (1999) Circuits of capital and transnational corporate spatial behaviour: Nestlé in Southeast Asia, International Journal of Sociology of Agriculture and Food, 8:3-20.

Rosenberg, B. (1997) 'Foreign investment in New Zealand: The current position', in P. Enderwick (ed.) Foreign Investment: The New Zealand Experience, Palmerston North: Dunmore Press, 23-65. 
Statistics New Zealand (SNZ) (2003) 'Employment and Enterprises by 6 Digit ANZSIC Division for New Zealand MeshBlocks 2003', Business Activity Statistics, Christchurch: Statistics New Zealand.

Statistics New Zealand (SNZ) (2005) 'Major Industry by Overseas Equity', Business Activity Statistics, Christchurch: Statistics New Zealand.

Story, M. (2004) 'Going for growth but get ready for tougher times ahead', Management, November, 24.

Taylor, M. and Asheim, B. (2001) 'The concept of the firm in economic geography', Economic Geography, 77, 315-328

Taylor, M.J. and Le Heron, R.B. (1977) 'Agglomeration, location and regional growth in New Zealand: The role of Auckland', in G. Bush and C. Scott (eds) Auckland at Full Stretch. Issues of the Seventies, Auckland: Auckland City Council and University of Auckland Board of Urban Studies, 188-200.

The Coca-Cola Company (2006) Coca-Cola Company, http://www.cocacola.co.nz/index.sm, as at February 2006.

The New Zealand Herald (2005) 'Coles plans Kmart NZ expansion', The New Zealand Herald, 31/10/2005.

Thrift, N. (1985) 'Taking the rest of the world seriously? British urban and regional research in a time of economic crisis', Environment and Planning A, 17, 7-24

Universal Business Directory (UBD) (2004) UBD Auckland Northland Business Directory 2004, Auckland: UBD.

Vautier, K.M. (1990) 'Trans-Tasman Trade and Competition Law', in K.M. Vautier; J. Farmer and R. Baxt (eds) CER and Business Competition - Australia and New Zealand in a Global Economy, Auckland: Commerce Clearing House, 73-114.

Wolfe, D. and Gertler, M. (2001), Globalization and economic restructuring in Ontario: From industrial heartland to learning region?', European Planning Studies, 9, $575-592$

Yeung, H. (2003) 'Practicing new economic geographies: A methodological examination', Annals Association of American Geographers, 93, 442-462.

Yeung, H. (2009), 'Regional development and the competitive dynamics of global production networks: An East Asian perspective', Regional Studies, 43, 325351. 